\title{
Reconsidering Dichotomies
}

\author{
Joan Sangster
}

My article obviously touched a nerve, judging by the responses, both on and off the record, that I have received. I want to reply here with brevity. My original piece was shorter than one of the replies; never intended as historiography, it was an opinion piece shaped by some alienations, discouragements and questions with the field as I saw it. Although short on footnotes, it was based on considerable reading, 'reflection and anxiety - the latter because in a field which has often lacked open and vigorous debate, it is sometimes difficult to offer even mild criticisms of work done by colleagues whom one respects.

I would stand by the three original aims I had in writing this polemic. First and foremost, I objected to the privileging of gender history OVER women's history, with the corollary assumption that the former offers a sharp break with existing feminist history and is methodologically and theoretically superior. Second, I wanted people to think critically about the political perspectives underlying the new gender history being written. Third, I tried to suggest that the existing Canadian women's history, though not immune to critique and sometimes limited (like all history) by the context in which it was written, should not be summarily dismissed.

1 I make special mention of 'reading' for one anonymous assessor of my rejected SSHRC grant who took special care to single out this article as evidence of "poor research." Given the other comments about me in the assessment, the SSHRC committee noted it did not endorse the "tone" of the assessor. The other assessor was more generous and positive. 
Never did I claim that gender history was a retrograde step for feminist or socialist historians, a 'bad' thing; indeed, I wrote the article at the same time I was developing a new course in gender history! Nor did I say, as one of the responses asserts, that there is only "one story" told by all gender historians, or that Canadian women's history to date was a homogeneous body of work. The assumption that women's history necessarily presumes 'woman' to be a "unitary category," while gender history does not, seems to me to oversimplify the writing in both gender and women's history, and again, dichotomizes these two areas of study, when they need not be polarized this way. ${ }^{2}$ Similarly, I find the suggestion that women's history is not "self sufficient because it can fall into the trap of presupposing the object of its inquiry"3 troubling because of the 'inadequacy' of women's history and attendant 'superiority' of gender history implied in these hypotheses.

I was reacting, then, to both published and unpublished claims that gender history was more advanced, on many levels, than women's history. I have certainly heard these claims in many oral presentations and I wanted to protest them before they became a 'received wisdom' in the profession. As Iacovetta and Kealey point out, this may have happened in part because new approaches engender overly enthusiastic advocates, but surely we should scrutinise very carefully the ostensible basis of such claims to intellectual superiority. Pronouncements which privilege gender over

2 This concern is raised in Joy Parr's recent article on gender history, in which she also tends to locate critics of gender history, feminist and anti-feminist alike, in the same oppositional group. "Within women's history, the new methodologies are also seen as a political danger, particularly when such studies place the unitary concept of woman under scrutiny." Joy Parr, "Gender History and Historical Practice," in Joy Parr and Mark Rosenfeld, eds., Gender and History in Canada (Toronto 1996), 11.

3 Mariana Valverde, "Gender History/Women's History: Is Feminist Scholarship Losing Its Critical Edge?" Journal of Women's History, 5, 1 (Spring 1993), 125. One of the reproaches I received about my "Dichotomies" piece was that I should have offered more criticism of historians such as Mariana Valverde and Joy Parr. I hope I've now atoned for my errors of omission. Since Mariana and I first met co-teaching Women's Studies, she may forgive, though not agree with, my position. 
women's history have been evident in a number of formal and informal conference and lecture statements by Canadian historians. I did not consider such statements 'off the record', and indeed thought it important to respond to them, because they create and reinforce the intellectual atmosphere nurturing assumptions of the preeminence of gender history. ${ }^{4}$

I also used a number of printed quotes to show this assumed superiority; not one of the authors responding justifies those quotes - and I should note that three of the four historians answering me were authors of them. It is rather unfortunate that the editors of left history did not make more of an effort to secure a heterogeneous, diverse set of replies as this would have created a more interesting, wide-ranging debate.

It is also unfortunate that historians publishing such statements cannot take responsibility for them and be more self-reflective, less defensive. The letter of Steven Penfold is a case in point.(See letter to the editor, p. 238) The claim that his quote was meant as "irony" or "sarcasm" just does not hold up (and anyway, why is such sarcasm directed at labour historians, who have tried, however imperfectly, to address questions of women's experience in their research?). I challenge any reader to look at that article and read the statement as ironic. What seems especially sad to me is that this is an impressive article which offers a very interesting exploration of both masculinity and femininity in a particular social context. It does not need the author's opening salvo declaring gender history superior; however, this is precisely the kind of statement which can easily slip into our work given the intellectual atmosphere I referred to above.

Thus, I do not think I created a non-existent dichotomy between women's and gender history; in fact, I was hoping to encourage reconsideration of the one I saw before me by pointing out that there

4 I now realize that some historians may not be comfortable with this direct style of debate. This is supported by my personal experience with the article; before it even went to press, one person involved instructed me to remove some quotes. 
were overlapping "continuities, similarities and problems rather than stark contrasts" between gender and women's history. ${ }^{5}$ A less dichotomous view of gender and women's history suggested in the unpublished introduction to a book on gender edited by Nancy Forestall, Kate Macpherson and Cecilia Morgan, and cited by my respondents, was not written when I wrote my left history piece, though later I did give them a draft of my article and I received theirs in return. I can hardly be criticized for not taking into account material I had not seen! ${ }^{6}$

Dichotomies, I think, are perpetuated by my respondents, as much as they are deconstructed by them. The metaphor I opened the article with was one of mothers and daughters (which as I pointed out later in the article does not 'work' if you look at what feminists have actually written); such a metaphor suggests a sometimes problematic, but also close relationship. ${ }^{7}$ The metaphor opening the Dubinsky and Marks piece, however, is quite different; in it, I represent the enemy, the distorting "bourgeois media." They represent themselves as the political demonstrators being distorted. Dichotomies indeed.

My comments about socialist feminist approaches to history, though they locate my position, were not made to set myself up as the 'correct' and virtuous feminist as is suggested, but rather to distance myself from radical feminist critiques of gender history published elsewhere, which are highly critical of gender history for the singular reason that it supposedly rejects a trenchant critique of patriarchy as the overarching theme in women's past. I made it clear that I did not endorse this singular critique and that I thought

5 Joan Sangster, "Beyond Dichotomies," 112.

6 Nor is it clear why it is permissable for some to quote unpublished sources, while I was informally criticized for doing so!

7 In a recent history of the Canadian Committee on Women's History, Veronica Strong-Boag uses the same metaphor of "mother and daughter generations." "In some people's eyes, I and those like me are the equivalent of 'old fogeys," "she writes, citing the Introduction to Gender Conflicts as a "polite reference to such differences." Veronica Strong-Boag, Work to be Done: The Canadian Committee on Women's History, August 1995. 
gender history had brought much to the profession - encouraging, for example, the integration of race, ethnicity and sexual orientation into our analyses - though I remain unconvinced that it has similarly encouraged a class perspective that was completely lacking before.

Like both groups of respondents, I approvingly quote the early Alison Prentice and Ruth Pierson article which called for the extension of feminist insights into all areas of historical writing. Gender relations as a historical problem, I argued, is not an entirely 'new' field of study; gender has evolved as a category of analysis within women's history, and surely historians of women have not used it simply as a "descriptive" rather than "analytic" tool as one reply claimed. ${ }^{8}$ What is wrong, I think, is to assume that gender as a field of study automatically serves up a more comprehensive, sophisticated version of the past, while women's history is narrow, partial and marginal.

Never did I critique works like those of Linda Gordon or Anne McClintock, the examples cited by Dubinsky and Marks, claiming they offered no new insights! Surely the point here - relating this to what I actually said - is that McClintock's book is not automatically superior because it focuses more on gender, while Gordon's is inferior because it focuses more on women. (I do not think that McClintock's theoretical inclination can be characterized as "nonsectarian," however, for it is more decidedly post-structuralist and psychoanalytic than previous analyses of imperialism, bringing both strengths and perhaps some weaknesses to her approach. But that is another issue).

Never did I say that the diversification that has accompanied gender history is a bad thing; never did I use language such as the "dead weight" of post-structuralism; never did I describe myself as the good feminist as opposed to other bad ones; never did I say that

8 Linda Kealey and Franca Iacovetta, "Women's History, Gender History and Dichotomies." Again, I think the word 'analytic' suggests theoretical superiority to less desirable 'descriptive.' 
feminists have no power (I can't even figure out where that issue comes from?). For these reasons, sections of the Dubinsky and Marks response, in terms of both the content and tone, are quite puzzling to me.

I think one problem with my original article was that it congealed and possibly blurred two issues: on the one hand, the rather straightforward claims that gender history is superior to women's history, and on the other hand, an exploration of the relationship between women's/gender history and post-structuralism. I would concede that the latter is a far more complex issue than I suggested, and one I think we need to address in a more comprehensive and vigorous manner.

While post-structuralist theories have been employed in the practice of both women's and gender history, I still think there is some connection between the way that gender history is currently being written (and indeed the emphasis on gender history as preferable) and post-structuralist theories. The two have blossomed in tandem. As Joy Parr states in a recent article: "The self conscious move towards the study of gender, rather than woman, ... began from the post-structuralist premise that identities were made in relationships." 9 This convergence between gender history and post-structuralism - which operates as a tendency more than as an absolute rule ${ }^{10}-$ is often portrayed as positive, complementary and healthy. It is assumed that post-structuralist approaches, (which are presumed, for instance, to explore rather than suppress differences, allowing for indeterminacy not simplistic certainties) fused with the study of gender, will produce a more sophisticated, complex history.

I think we need a good debate about the assumptions. I believe that post-structuralism - which is far from monolithic in itself -

9 Joy Parr, "Gender History and Historical Practice," 14.

10 It is too simple to say that everyone who stresses an analysis of gender also embraces post-structuralist theory. For example, Anna Clark is sympathetic to the former but rather critical of the latter in her intervention in the "Gender History/Women's History," debate. 
offers tools of analysis and valuable new means of exploring both women's and gender history: I admit to utilizing these tools in my own writing. But I think there are drawbacks and dangers associated with these theories which also need to be discussed. As a wide variety of feminist and Marxist writers from Linda Alcoff to Alex Callinicos, from Nancy Hartstock to Pauline Roseneau, from Joan Hoff to Bryan Palmer, from Kate Soper to Barbara Christian (quite a disparate group there!) have argued, some post-structuralist theory stands in opposition to some feminist ideals and certainly to Marxism; some aspects of these theories encourage apolitical readings of the world; some parts of post-structuralism challenge, in worrying ways, notions of historical agency, experience, structure, narrative and causation, and so on. ${ }^{11}$

I am not convinced that post-structuralism has shattered existing, ossified approaches to women's history, without bringing some negative repercussions in its wake. As others have pointed out, the dissolving of "master narratives" has also implied the

11 This is, of course, a very partial list, and one which includes very diverse criticisms of post-structuralism. Nancy Hartstock, "Foucault on Power: A Theory for Women?,"in Linda Nicholson, ed., Feminism and Postmodernism (New York 1990); Linda Alcoff, "Cultural Feminism versus Post-structuralism," Signs, 13, 3 (1988). Alex Callinicos, Against postmodernism: a marxist critique (London 1989); Joan Hoff, "Gender as a Postmodern Category of Paralysis," Women's History Review, 3 (1994); Kate Soper, Troubled Pleasures (London 1990); Bryan Palmer, Descent into Discourse: The Reification of Language and the Writing of Social History (Philadelphia 1990); Pauline Roseneau, Postmodernism and the Social Sciences: Insights, Inroads, Intrusions (Princeton 1992); Barbara Christian, "The Race for Theory," Feminist Studies, 14, 1 (1988). For a similar concern about the dominance of this theory and its elitism see Bell Hooks, Talking Back: Thinking Feminist, Thinking Black (Boston 1989). The importance of humanism and a clear Black feminist 'standpoint' to feminists like Patricia Hill Collins, Black Feminist Thought: Knowledge, Consciousness and the Politics of Empowerment (New York, 1990) would also stand in contradiction to some post-structuralist writing. See also Nancie Caraway, Segregated Sisterhood: Racism and the Politics of American Feminism (Knoxville 1991), esp. Ch. 3. 
dissolution of narratives advocating social transformation. The emphasis on discursive constructions of reality, the fragmentation of all categories and the hesitancy to 'name' experience or privilege certain structures of oppression all raise an unsettling doubt: "can feminist theory be postmodern and still retain an interest in emancipation?",12

A critical analysis of the convergence of post-structuralism and historical research, and of the problems, as well as the potential, of using these theories to excavate both gender and women's history would thus be useful. ${ }^{13}$ What I question is the prevailing assumption that gender history as the field, post-structuralism as the method, equals a superior, more broad-minded history, distinguished by its openness to heterogeneity, new questions, the texture of specificities - in contrast to rigid "[immobilized] structures"14 associated with other approaches. I don't think we should box ourselves into a mould that creates such an intellectual hierarchy, preventing valid criticisms of post-structuralism and portraying this one approach as 'more advanced' with those attempting to offer differing views as 'backward.'

I suspect some of the authors responding to me edge more sympathetically than I would towards post-structuralism - given

12 Seyla Benhabib, "Feminism and Postmoderism," in Linda Nicholson, ed., Feminist Contention: A Philosophical Exchange(New York 1995). For some discussion of this in relation to Black feminist thought see Nancie Caraway, Segregated Sisterhood.

13 Some historians have tried to explore the 'middle ground' on these issues, explicating the ways in which post-structuralist theories can potentially enhance, but also may detract from feminist historical scholarship. An example might be Kathleen Canning, "Feminist History and the Linguistic Turn," Signs 19(2) 1994 or Nancy Fraser and Linda Gordon, "A Genealogy of Dependency: Tracing a Keyword of the U.S. Welfare State," Signs, 19(2), 1994. And a number of theorists have also tried to read post-structuralism critically, integrating insights into feminist and materialist analysis. I am refraining here from a footnote contest because I think this is a large topic which requires more in-depth exploration.

14 Joy Parr, "Gender History and Historical Practice," 21. 
the definitions used in their replies. ${ }^{15}$ At the same time, I think the need for a more intense and critical debate about post-structuralism is implied by my colleagues Iacovetta and Kealey, whose longer historiographical review of the literature I found useful. Many of their questions echo mine and so I find little to quibble with (except of course their friendly charge that I "simplify" and "misrepresent") in their piece. As both they and I point out, for example, the work of Canadian gender and women's historians can not be divided sharply by generation and theoretical inclination, for in fact they overlap. And they note, as I do, that there has actually been very little written on masculinity in Canada. My advice was not to ban masculinity as a field of study, but rather to suggest that we interrogate the politics of writing on masculinity very rigorously for some of the existing writing has side-stepped hard questions about power relations. ${ }^{16}$

Their proposition that we investigate gender as a 'standpoint' rather than a field of study is an interesting one. I tend to think it must by necessity remain both, for gender history does not by definition embrace a common approach to theory and methodology, let alone an oppositional or even feminist standpoint. A critical, feminist analysis of gender - applied to women's or gender history - could constitute what Maureen Cain calls a "relational standpoint," distinguished by its particular "politics,

15 This is perhaps more true of Dubinksy and Marks. But see also the definition of Franca Iacovetta and Linda Kealey of the "social construction of identities." From a previous piece in which I note Linda Kealey's public address to the Teaching Women's History conference, I would have characterized her as more critical of post-structuralism (which I think was true in that address), see Joan Sangster, "Facing Our Differences, Forging Differences: The Challenges of Creating an Inclusive Curriculum," in Bettina Bradbury, et al, eds., Teaching Women's History, Challenges and Solutions (Athabasca 1995). Also, Franca Iacovetta's Such Hardworking People: Italian Immigrants in Postwar Toronto (Montreal 1992) draws lightly, if at all on post-structuralism, so I do not want to simplistically characterize them as post-structuralists.

16 This critical view of some studies of masculinity is also noted by Mariana Valverde in "Gender History/Women's History: Is Feminist Scholarship Losing Its Critical Edge?" 
theory, reflexivity, choice of worldview (and certainly containing debates within it)." ${ }^{17}$ What seems important here is not to privilege an area or topic of research but to contemplate the political, oppositional and feminist possibilities, using such a standpoint, for all areas of study.

Like Iacovetta and Kealey, I note that the call for a study of gender relations came many years ago from historians like Natalie Zemon Davis. That call remains relevant today, but it does not negate the need to continue with the project of women's history as a distinct field of study and as a political enterprise. My article ended with a call for a popular front of gender and women's historians, with neither claiming superiority, but both contemplating common political and academic issues - a position I thought implied respect and openness. I still think this popular front is necessary, and that feminist perspectives should be central to our debates in gender and women's history - and all of us in the profession, no matter what our role or position (not just those in the "critically strategic" positions of supervising graduate students) should be thinking about these aims.

Contrary to Dubinsky and Marks, I do not think that this call represents a "narrow" vision. Our vision will be narrowed if we don't debate these issues, vigorously and passionately, but with tolerance, patience and critical self-reflection. Intellectual disagreement can be sharp without entailing personal antipathy. If we can pursue debate in this positive way, collectively, we may all benefit.

17 See Maureen Cain's definition of 'relational' standpoint, modifying other feminist definitions in "Realist Philosophy and Standpoint Epistemologies of Feminist Criminology as a Successor Science," in Lorraine Gelsthorpe and Allison Morris, eds., Feminist Perspectives on Criminology (Philadelphia 1990). 